\title{
Giants and Bizarres: Body Size of Some Southern South American Cretaceous Dinosaurs
}

\author{
GERARDO V. MAZZETTA ${ }^{a, *}$, PER CHRISTIANSEN ${ }^{b, t}$ and RICHARD A. FARIÑA ${ }^{a, \ddagger}$ \\ a Departamento de Paleontología, Facultad de Ciencias, Universidad de la República, Iguá 4225, 11400 Montevideo, Uruguay; \\ ${ }^{\mathrm{b}}$ Department of Vertebrates, Zoological Museum, Universitetsparken 15, DK-2100 Copenhagen Ø, Denmark
}

Body masses of some South American dinosaurs are estimated. The sauropod Argentinosaurus huinculensis reached 73 tonnes, and therefore, is the largest of all land animals whose mass has been rigorously obtained. Another sauropod, Antarctosaurus giganteus, was the second largest, at nearly 69 tonnes, while Antarctosaurus wichmannianus reached 34 tonnes. A third sauropod, the bizarre-looking Amargasaurus cazaui, was much smaller, with a body mass of only 2.5 tonnes. Among theropods, the body mass of the strangely looking, horned Carnotaurus sastrei, was volumetrically estimated at 1.5 tonnes, while allometric equations on limb measurements yielded overestimations. Moreover, the holotype specimen of Giganotosaurus carolinii (MUCPv-CH-1) was about as large as the average-sized Tyrannosaurus rex, and only marginally smaller than "Sue", the largest specimen. However, a new dentary of Giganotosaurus (MUCPv-95) is $8 \%$ longer than that of the holotype. Assuming geometric similarity, that individual must have had a body mass above 8 tonnes and hence must have been the largest theropod ever found.

Keywords: South American dinosaurs; Argentinosaurus; Antarctosaurus; Amargasaurus; Giganotosaurus; Carnotaurus

\section{INTRODUCTION}

Dinosaurs were the dominant forms of the Cretaceous tetrapod faunas of southern South America, as they were in general throughout the Mesozoic ecosystems (Wing et al., 1992). Among the dinosaurs, sauropods are particularly interesting from a biological point of view since some of them constituted the largest terrestrial vertebrates by a wide margin (Benton, 1990; Christiansen, 1997; 2002). The large-bodied Laurasian sauropods are generally the more well known, and some of these were of truly gigantic proportions, but some

*E-mail: mazzetta@fcien.edu.uy

†E-mail: p2christiansen@zmuc.ku.dk

${ }^{\ddagger}$ Corresponding author. E-mail: fari a@fcien.edu.uy

ISSN 0891-2963 print/ISSN 1029-2381 online @ 2004 Taylor \& Francis Ltd DOI: $10.1080 / 08912960410001715132$ sauropods from southern South America appear to have rivalled or even exceeded the hitherto largest known Laurasian forms.

It is difficult to say to what extent the known southern South American taxa might have characterised the Cretaceous continental assemblages of all of South America. However, it seems reasonable to suppose that most of the dinosaur groups recorded in southern South America were present in other regions of the continent as well, where relatively less palaeontological excavations have been made and where preservation conditions are not as favourable as in Patagonia. Bonaparte (1986) has pointed out that most of the dinosaurian taxa of the South American Cretaceous were indicative of the endemism observed throughout most of the southern supercontinent of Gondwana. This process was likely brought about by the relative geographic isolation of Gondwana and Laurasia, which probably began in the Middle Jurassic and lasted until the Campanian (Bonaparte, 1986, 1996a). However, this palaeobiogeographic issue still needs further study to be fully understood. The current knowledge of the dinosaur fauna of the South American Cretaceous indicates that it shows reasonably good affinities with the Cretaceous faunas of other Gondwanan landmasses: Africa, Indo-Madagascar, and Australia (Bonaparte, 1986; Sampson et al., 1998), and more substantial differences with the Laurasian fossil record (Bonaparte and Kielan-Jaworowska, 1987).

Several of the southern South American dinosaurs appear different from their Laurasian relatives. The dicraeosaurine sauropod Amargasaurus cazaui appears to have taken the elongated, bifurcate neural 
spines, common in the neck and anterior dorsal regions of diplodocoids, to extremes, as they resemble large spikes. Among the most interesting forms of titanosaurian sauropods known to date are Argentinosaurus huinculensis, widely regarded as the largest dinosaur hitherto known (Bonaparte and Coria, 1993; Appenzeller, 1994; Paul, 1994, 1997), and Antarctosaurus giganteus, which appears to have been nearly as large. Aspects of the palaeobiology of these giants have not been investigated, nor have rigorous body mass estimates been attempted. Two recent theropod discoveries on Gondwana, although incomplete or fragmentary, appear to have equalled or even exceeded in size to the largest and complete Tyrannosaurus rex, the specimen FMNH PR2081 informally known as "Sue" (Horner and Lessem, 1993). One of them is the predatory dinosaur Carcharodontosaurus saharicus, a species first recognised in 1927 and represented by new material (a skull) discovered in the earliest Late Cretaceous (Cenomanian) of the Kem Kem region of Morocco (Sereno et al., 1996). The other, and probably the largest terrestrial flesh-eater ever found, is Giganotosaurus carolinii, from the mid-Cretaceous (Albian-Cenomanian) of north-western Patagonia, Argentina (Coria and Salgado, 1995; Calvo and Coria, 1998).

Palaeobiological studies of South American dinosaurs are scarce (Casamiquela, 1978; Mazzetta et al., 1998; Blanco and Mazzetta, 2001; Mazzetta and Blanco, 2001). From a biological point of view, many dinosaurian taxa of southern South America are interesting and in need of palaeobiological analysis, particularly the above-mentioned huge titanosaurian sauropods and the large-bodied theropod, as they appear to represent size maxima in dinosaur evolution. In this paper, we address the estimation of their body size to provide a basis for further palaeobiological studies related to locomotion and other palaeoecological issues. Additionally, some bizarre Patagonian dinosaurs like the small sauropod A. cazaui and the moderately-sized theropod Carnotaurus sastrei are also included as they are specimens constituted by nearly complete skeletons.

\section{MATERIALS AND METHODS}

\section{Included Taxa}

An incomplete femur attributed to A. huinculensis (labelled MLP-DP 46-VIII-21-3), and skeletal material belonging to its holotype (PVPH-1) and also to the holotype of another titanosaurian sauropod, A. giganteus (MLP 23-316), were used for this study. The mentioned material is housed at the exhibition of the Museo de La Plata, Argentina, except for the holotype of A. huinculensis, which is exhibited at the Museo Municipal "Carmen Funes" of Plaza Huincul, Neuquén, Argentina. Additionally, the principal hindlimb bones of Antarctosaurus wichmannianus were included. The latter material was collected in Chubut, Argentina (Huene, 1929), but presently is housed at the Field Museum of Natural History in Chicago. At present it appears uncertain if $A$. wichmannianus is a different species from A. giganteus, but in this paper they are treated as two species (the impressive size difference may be considered another indication that they represent two species). The femur (FMNH P13019) and associated tibia (FMNH P13020) are not from the same hindlimb (the femur is a right side bone, unlike the tibia) but were found together, indicating that they must have belonged to the same animal. This is further corroborated by the fact that the size and proportions appear right for one individual, and since the texture and colour of the two bones is identical. Although the bones are of gigantic dimensions they clearly belong to an individual distinctly smaller than the colossal A. giganteus (the length of the femur in MLP 23-316 is $2350 \mathrm{~mm}$ compared to $1855 \mathrm{~mm}$ in FMNH P13019).

The skeletal cast of $A$. cazaui, mounted at the exhibition of the Museo Argentino de Ciencias Naturales "Bernardino Rivadavia", Buenos Aires, Argentina, and additional material housed at the same institution, labelled MACN-N 15 (holotype), were also used in the analyses. Additionally, limb bone measurements of the holotype specimen of C. sastrei (MACN-CH 894) published by Bonaparte et al. (1990), and measurements on appendicular bones of the disarticulated holotype specimen of G. carolinii (MUCPv-CH-1), were also considered.

All the species studied here were found in Patagonia, Argentina. A. giganteus is from the Río Neuquén Formation, Early Cenomanian, Neuquén Province (north-western Patagonia) (Huene, 1929), and A. cazaui (Fig. 1) is from the La Amarga Formation, Late Neocomian, Neuquén Province (Salgado and Bonaparte, 1991). A. huinculensis and G. carolinii are both from the Río Limay Formation, mid-Cretaceous (Albian-Cenomanian), Neuquén Province (Bonaparte and Coria, 1993; Coria and Salgado, 1995), while the other theropod included in the study, C. sastrei (Fig. 2), was collected

\footnotetext{
"Institutional abbreviations: CN, Zoology Museum, Copenhagen University; FMNH, Field Museum of Natural History, Chicago, USA; HMN, Museum für Naturkunde der Humboldt Universität, Berlin, Germany; MACN, Museo Argentino de Ciencias Naturales “Bernardino Rivadavia", Buenos Aires, Argentina; MLP-DP (and also MLP), Departamento Científico de Paleontología de Vertebrados of the Museo de La Plata, La Plata, Argentina; MUCPv-CH, Museo de Geología y Paleontología de la Universidad Nacional del Comahue, Paleontología de Vertebrados, El Chocón collection, Neuquén, Argentina; PVPH, Museo Municipal "Carmen Funes", Plaza Huincul, Neuquén, Argentina.
} 


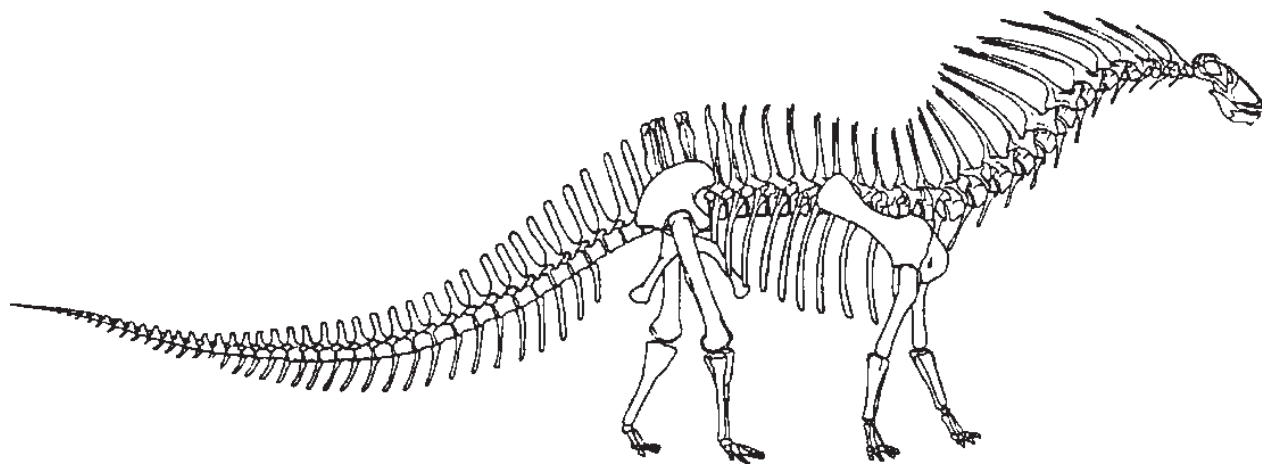

FIGURE 1 Amargasaurus cazaui. Reconstruction of the skeleton. From Salgado and Bonaparte (1991).

from northern Chubut Province (Bonaparte, 1985; Bonaparte et al., 1990). It was formerly believed to be from the Albian-Cenomanian Gorro Frigio Formation but later was referred to the lower section of La Colonia Formation, Late Cretaceous (Campanian-Maastrichtian) of Patagonia (Ardolino and Delpino, 1987).

\section{Estimation of Body Mass}

The body mass of the sauropod A. cazaui was estimated by 3-D mathematical slicing (Henderson, 1999). For this purpose the width and height of its body (taking as reference its life-sized skeletal cast) was measured at regular intervals from the snout to the tip of the tail. Each pair of measurements was subsequently treated as the larger and lesser diameters of an ellipse. The outer surfaces between successive ellipses were smoothed to have a continuous outline of the body. Limb masses were calculated separately, and limbs were assumed to be cylinders. Following Alexander (1985), an overall density of $1000 \mathrm{~kg} \mathrm{~m}^{-3}$ was assumed for the body of Amargasaurus. Little difference is obtained considering a body density of $950 \mathrm{~kg} \mathrm{~m}^{-3}$, as for the sauropods in Table I.
Unfortunately, the available skeletal material of the sauropods A. huinculensis and Antarctosaurus spp. (and the G. carolinii) is too fragmentary for a reliable model reconstruction to be made. Those sauropods are titanosaurs (e.g. Novas, 1997b; Salgado et al., 1997a), which were the dominant sauropods in the Late Cretaceous (Upchurch, 1995). Although the detailed anatomy of the titanosaurs includes a great number of apomorphies compared to more archaic sauropods (Salgado et al., 1997a,b), the overall body outline appears rather plesiomorphic for a sauropod, with rather long, but robust limbs (e.g. Borsuk-Bialynicka, 1977; Salgado et al., 1997a; Wilson and Sereno, 1998), forelimbs not apomorphically shortened relative to the hindlimbs as in the diplodocoids, and lacking the apomorphically elongated neck and very elongated tail of these taxa with up to 82 caudal vertebrae (Christiansen, 1996). The few known fairly complete titanosaurs (e.g. Saltasaurus loricatus) appear to have been rather stoutly built with moderately long necks and tails, which has influenced popular reconstructions of Argentinosaurus (e.g. Appenzeller, 1994; Bonaparte, 1996b: p. 142). Giganotosaurus is a basal tetanurine theropod and most analyses indicate that it is a carnosaur (sensu Gauthier, 1986). It is most frequently placed alongside the almost equally

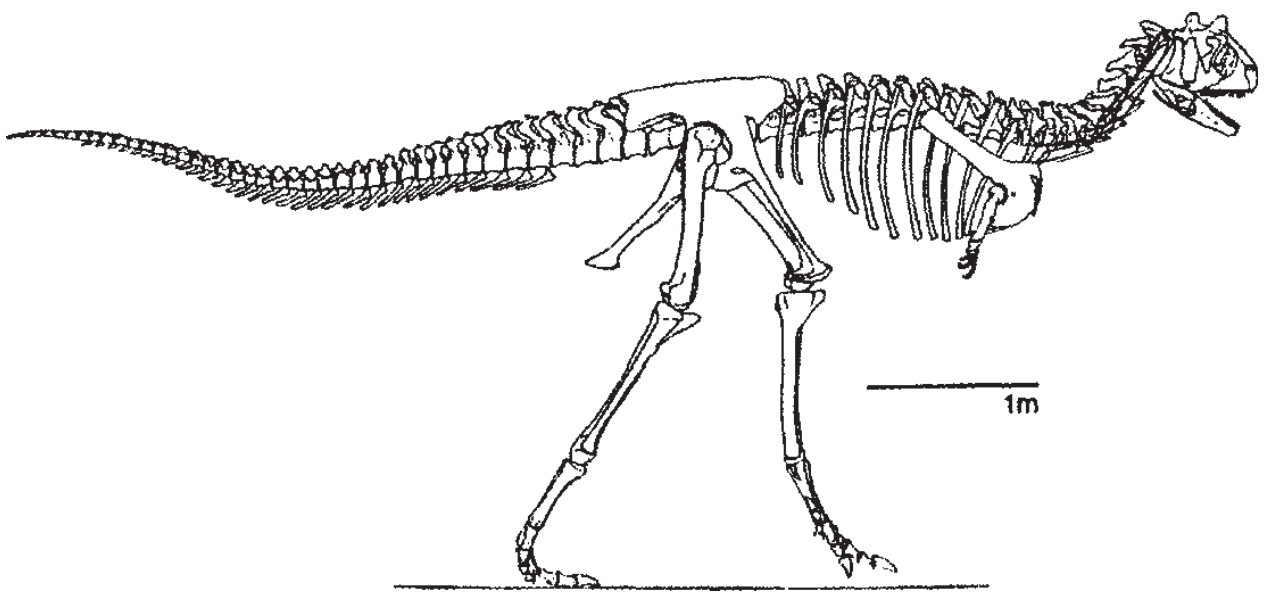

FIGURE 2 Carnotaurus sastrei. Reconstruction of the skeleton. From Bonaparte et al. (1990). 
TABLE I Overall lengths, model-based body masses, and bone dimensions for a set of selected sauropods

\begin{tabular}{|c|c|c|c|c|c|c|c|c|c|}
\hline \multirow[b]{2}{*}{ Species } & \multirow[b]{2}{*}{ Overall length (m) } & \multirow[b]{2}{*}{ Body mass (kg) } & \multicolumn{7}{|c|}{ Bone dimensions } \\
\hline & & & $\mathrm{fl}$ & tl & fil & $\mathrm{fw}$ & $\mathrm{fp}$ & tp & va \\
\hline Amargasaurus cazaui & 9.1 & 2600 & 1050 & 640 & 640 & 284 & 440 & - & 11,651 \\
\hline Apatosaurus louisae & 22.8 & 20,600 & 1785 & 1115 & 1175 & 536 & 832 & 531 & 64,128 \\
\hline Brachiosaurus brancai & 21.8 & 39,500 & 2028 & 1120 & 1190 & 590 & 945 & 518 & 148,597 \\
\hline Camarasaurus supremus & 13.8 & 9300 & 1341 & 824 & 818 & 423 & 542 & 404 & 44,748 \\
\hline Cetiosaurus oxoniensis & 16.5 & 15,900 & 1660 & 974 & - & 471 & 715 & 416 & - \\
\hline Dicraeosaurus hansemanni & 14.2 & 5700 & 1220 & 760 & 750 & 313 & 521 & 335 & 14,833 \\
\hline Diplodocus carnegiei & 25.6 & 16,000 & 1540 & 1010 & 1050 & 412 & 589 & 356 & 43,004 \\
\hline Euhelopus zdanskyi & 10.5 & 3800 & 955 & 602 & 618 & 261 & 400 & 264 & 12,441 \\
\hline Haplocanthosaurus priscus & 14.8 & 12,800 & 1275 & - & - & 309 & 531 & - & 20,548 \\
\hline Mamenchisaurus hochuanensis & 20.4 & 15,100 & 1275 & 860 & 865 & 380 & 621 & 331 & 61,850 \\
\hline Omeisaurus tianfuensis & 20.2 & 9800 & 1215 & 855 & 860 & 331 & 526 & 432 & - \\
\hline Opisthocoelicaudia skarzynskii & 11.3 & 8400 & 1395 & 810 & 830 & 430 & 644 & 424 & 26,507 \\
\hline Shunosaurus lii & 9.9 & 3600 & 865 & 660 & 655 & - & 393 & 291 & - \\
\hline
\end{tabular}

The body mass values shown were recalculated from Christiansen (1997), except for the cases of Euhelopus, Haplocanthosaurus, Opisthocoelicaudia (data taken from Paul, 1997), and Amargasaurus (datum calculated for this paper). Abbreviations: fl, length of the femur; tl, length of the tibia; fil, length of the fibula; $\mathrm{fw}$, distal width of the femur across the condyles; fp, midshaft perimeter of the femur; tp, midshaft perimeter of the tibia; and va, cross-sectional area of the centrum of the second dorsal vertebra. All bone dimensions are in $\mathrm{mm}$, except va (in $\mathrm{mm}^{2}$ ).

massive African Carcharodontosaurus in the Carcharodontosauridae (Sereno et al., 1996), a taxon widely regarded as the sister taxon to the Allosauridae (Sereno et al., 1996; Hutchinson and Padian, 1997; Novas, 1997b).

A number of Model II, Reduced Major Axis (RMA) or geometric mean regression analyses were performed (see Ricker, 1984, and Sokal and Rohlf, 1995 for computational background) in order to predict the body masses of Argentinosaurus and Antarctosaurus from measurements taken on their rather scarce skeletal remains (Fig. 3). Those analyses were performed on a log-transformed (base-10) database consisting of model-based body mass estimates and measurements of bone dimensions (such as lengths of the femur, tibia, and fibula, distal width of the femur across the condyles, midshaft perimeter of the tibia, and crosssectional area of the centrum of the second dorsal vertebra) in an array of 13 other sauropods listed in Table I. Clearly, both kinds of variables (that is, body mass and bone dimensions) are subject to measurement error as well as inherent, biological variability, thus requiring a Model II regression analysis (Sokal and Rohlf, 1995). Moreover, a geometric mean regression line is justifiable for prediction purposes when, as in this case, the sample (data) was withdrawn from a bivariate population whose frequency distribution is unknown.

The goodness of fit of the linear regression analysis was evaluated considering the correlation coefficient. A simple average (arithmetic mean) was

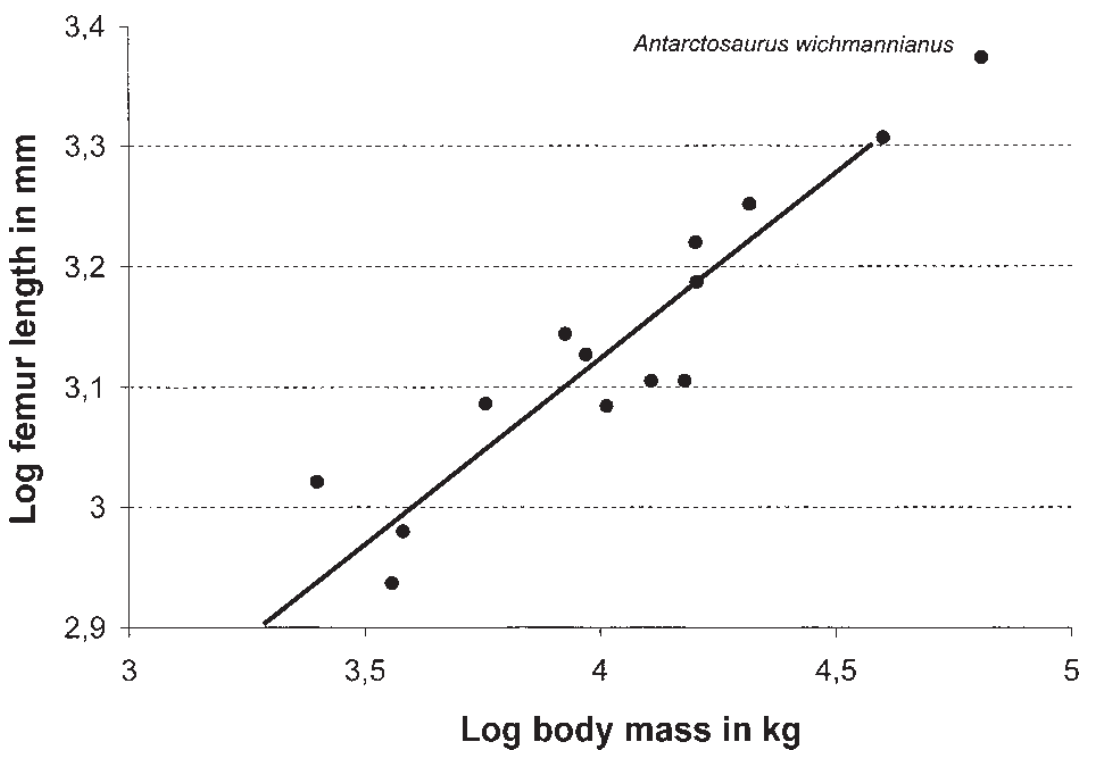

FIGURE 3 Two sample graphs (A, log body mass vs. $\log$ femur length and B, log body mass vs. $\log$ femur length cross sectional area of posterior articulating face of second dorsal vertebra), each showing the scatter of points on which a regression in Table II is based, the calculated regression line, and the predicted body masses of Argentinosaurus huinculensis and Antarctosaurus wichmannianus. 
computed to estimate the body mass of the Patagonian sauropods taking into account the different body masses predicted by each equation.

The 13 sauropod species included in Table I represent a wide phylogenetic spectrum and their body masses had been found by weighing scale models in air and water in the case of Apatosaurus, Brachiosaurus, Camarasaurus, Cetiosaurus, Dicraeosaurus, Diplodocus, Mamenchisaurus, Omeisaurus and Shunosaurus (data from Christiansen, 1997). Commercially available models (see, e.g. Alexander, 1985, 1989) were avoided, as they are proportionally incorrect (Paul, 1997; Christiansen, 1997, 2000). However, the values from Christiansen (1997) were recalculated using a slightly higher overall density $\left(950 \mathrm{~kg} \mathrm{~m}^{-3}\right)$, as the $900 \mathrm{~kg} \mathrm{~m}^{-3}$ used in that paper may be slightly too low. Most neosauropods have extensively pneumatised vertebrae, particularly the cervicals, which would tend to lower overall density. However, these animals are also very large, implying a proportionally greater amount of skeletal tissue (Christiansen, 2002), particularly appendicular skeletal tissue, and consequently, they should have had a higher overall density.

The body masses of Euhelopus, Haplocanthosaurus, and Opisthocoelicaudia were taken from Paul (1997). These were obtained from plasticine scale models, following a skeletal restoration. The body mass of Amargasaurus was also included in the database (see Table I) and its corresponding value was calculated by 3-D mathematical slicing (Henderson, 1999), as noted above. The right femur of the skeletal mount of Brachiosaurus brancai (HMN SII) consists of the original material proximally and distally (Janensch, 1950). Consequently, only the measurement corresponding to the distal part of the femur was included in the database. The diaphysis is lacking, and thus, the bone length is not available. Instead, the length of the femur of B. altithorax (FMNH 25107) was used, though this specimen appears to have been subequal in size to HMN SII (Paul, 1988; Christiansen, 1997).

Several of the dorsal vertebrae included in the holotype of Argentinosaurus appear rather well preserved (Bonaparte and Coria, 1993), which allowed the estimation of its body mass from regressions on the cross-sectional area of the centrum of the second dorsal vertebra. At present only the femoral diaphysis of Argentinosaurus is available (from the specimen MLP-DP 46-VIII-21-3), although a colossal femur (topotype) has also been referred to this species (Bonaparte, 1996b). Unfortunately, the latter specimen, which is exhibited at the Museo Municipal "Carmen Funes", has been anteroposteriorly compressed in fossilization, making it rather unreliable for body mass estimation based on its cross-sectional geometry. The "tibia" of the holotype (Bonaparte and Coria, 1993) is clearly not a tibia but a fibula. It lacks both the proportions and anatomical characters of a tibia.
The purported "cnemial crest" is merely the anteroproximal expansion common to sauropod fibulae, and the entire bone bears resemblance to the fibulae of other sauropods. Hence, the body mass of Argentinosaurus can also be regressed on its fibular length. Additionally, the fibular length $(1550 \mathrm{~mm})$, as well as the femoral midshaft perimeter of the specimen MLP-DP 46-VIII21-3 $(1180 \mathrm{~mm})$, were used for prediction of femoral length in Argentinosaurus. This procedure was used to check the utility of the paratype material to predict the body mass of the holotype specimen. Accordingly, femoral length was regressed on fibular length and also on femoral midshaft perimeter considering the measurements taken on the 13 sauropod species mentioned in Table I plus A. wichmannianus (Table III). The extra measurement taken in $A$. wichmannianus was its femoral midshaft perimeter $(873 \mathrm{~mm})$.

Finally, multivariate regression analyses for prediction of sauropod body mass were performed on several "independent" variables with the aim of establishing if this technique would result in a better prediction of body mass than would be possible by any single "independent" variable. However, when a biological sample is considered, multivariate regression analysis of a "dependent" variable on a series of "independent" variables will inevitably lead to intercorrelation of the latter ones. Clearly, the proportions of an animal's backbone cannot be uncorrelated with the proportions of its limbs. Hence, tolerance values, eigen values and condition indices of the equation were computed to evaluate the intercorrelation of the "independent" variables. All data values were log-transformed (base 10) prior to statistical (bivariate or multivariate) analyses.

The lengths of the femora, tibiae and fibulae, as well as the midshaft perimeters of the femora and tibiae, were measured with a measuring tape. The distal widths of the femora across the condyles were measured with a large caliper. The crosssectional areas of the centra of the second dorsal vertebrae were estimated from their diameters (dorsoventral and lateromedial) using the standard formula for the area of an ellipse.

The body masses of the theropods Carnotaurus and Giganotosaurus were estimated after the bivariate and multivariate regression equations in Christiansen and Fariña (2004). Those equations were obtained using a database of 16 theropod species, ranging in size from 16.5-kg Ornitholestes to 6300-kg T. rex and comprising a wide phylogenetic sample.

\section{RESULTS}

\section{Sauropods}

The estimated body mass for A. cazaui was $2600 \mathrm{~kg}$, when a normal vertebrate density of $1000 \mathrm{~kg} \mathrm{~m}^{-3}$ is used. The consideration of such a density value is 
suggested by its stoutly built body, which does not show the common excavations (pleurocoels) found in the dorsal vertebrae of other sauropods. That figure is only slightly lowered to $2460 \mathrm{~kg}$ if the density assumed for the rest of the sauropods $\left(950 \mathrm{~kg} \mathrm{~m}^{-3}\right)$ is used.

The rest of the sauropod species studied here are of very large dimensions. Indisputably, the largest dinosaur (and also the largest land animal) that is known from a reasonably complete skeleton is B. brancai. The skeleton of the specimen HMN SII is mounted at the Museum für Naturkunde in Berlin, and major portions of this skeleton can also be viewed (as casts) in the composite mount of B. altithorax at the Field Museum of Natural History in Chicago. The body mass of Brachiosaurus has been greatly exaggerated in many publications (e.g. Colbert, 1962; Norman, 1985; Benton, 1988; Gunga et al., 1995; Christian et al., 1999).

The fragmentary skeletal remains of Argentinosaurus (see Figs. 4 and 5) are distinctly larger than the corresponding parts of Brachiosaurus. For instance, some of its dorsal vertebrae are more than a meter and a half tall $(159 \mathrm{~cm}$ for the reconstructed first? dorsal) and the fibula is $155 \mathrm{~cm}$ long (described as a tibia by Bonaparte and Coria, 1993: Fig. 1), compared to $119 \mathrm{~cm}$ in HMN SII. Moreover, the fragmentary femoral diaphysis attributed to Argentinosaurus measures no less than $118 \mathrm{~cm}$ in its narrowest cross-sectional perimeter, compared to $94 \mathrm{~cm}$ in Brachiosaurus altithorax FMNH 25107 (203 cm long), and $82 \mathrm{~cm}$ in the rather slender specimen HMN XVI of B. brancai ( $211 \mathrm{~cm}$ long). Evidently, the body mass of Argentinosaurus was impressive. Some researchers have guessed its mass at close to 100 tonnes (Appenzeller, 1994), and Paul (1997) estimated its mass to be 90 tonnes.

When using a simple geometric scaling with fibular length in Brachiosaurus HMN SII $(119 \mathrm{~cm})$, which phylogenetically is the closest to Argentinosaurus in the database (Table I) (Salgado et al., 1997a; Wilson and Sereno, 1998), a value of $87287 \mathrm{~kg}$ is obtained. Camarasaurus is the outgroup to the Titanosauriformes (Brachiosaurus + Titanosauria) (Salgado et al., 1997a; Wilson and Sereno, 1998) and its overall body shape bears closer resemblance to

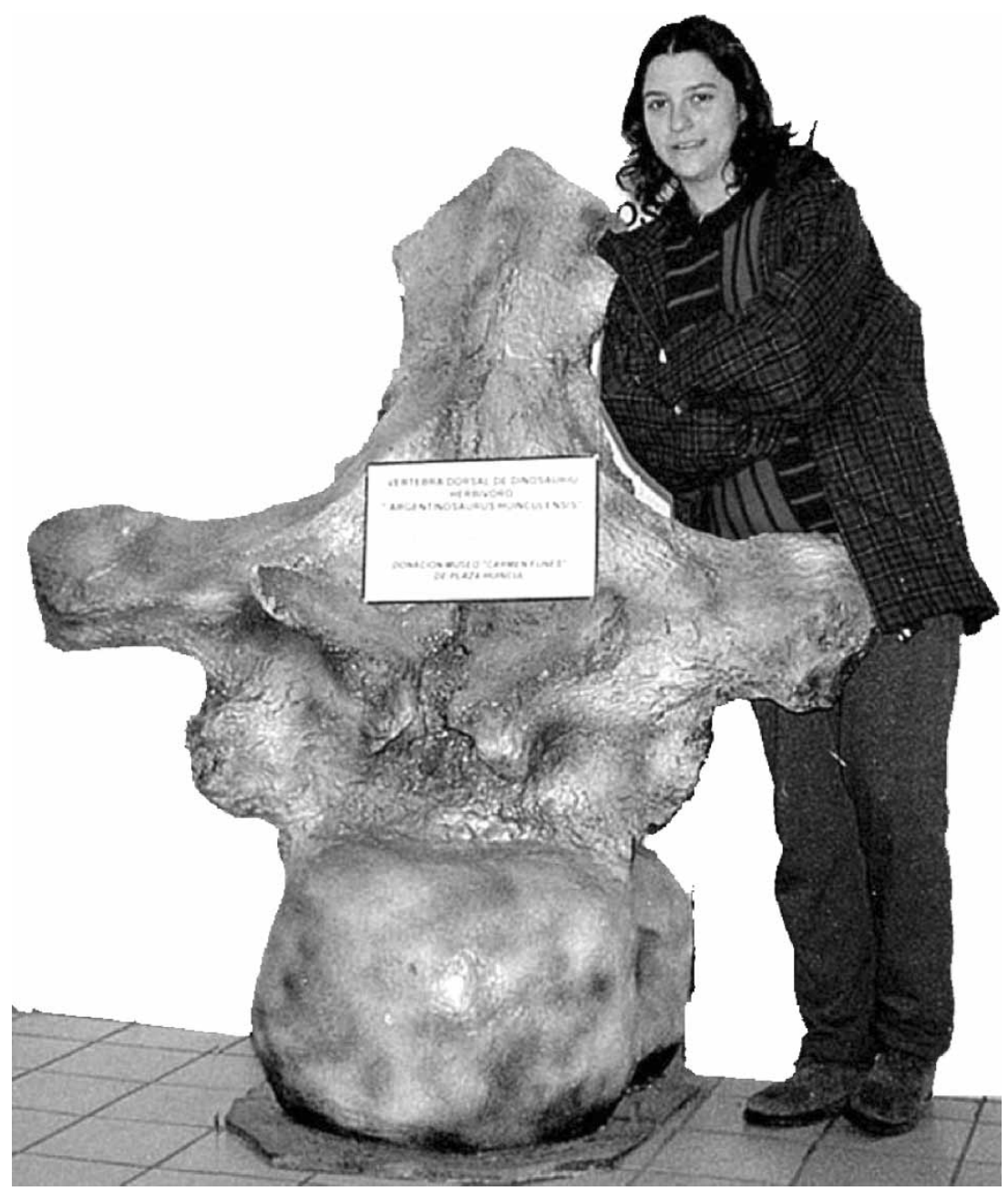

FIGURE 4 Cast of a vertebra of the giant sauropod Argentinosaurus huinculensis, as exhibited in the Museo Municipal del Chocón, Neuquén, Argentina (Photograph taken by L. Quagliotto). 


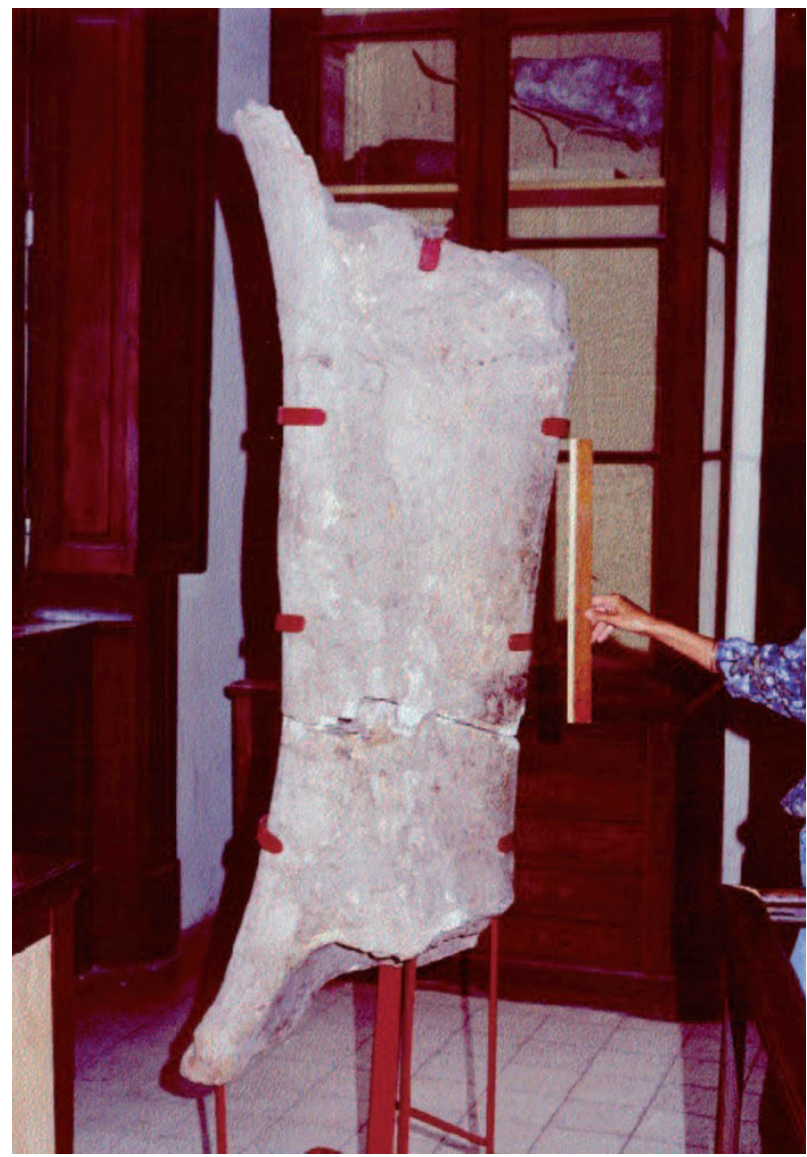

FIGURE 5 Fragment of a huge femur of Argentinosaurus huinculensis, as exhibited in the Museo de La Plata.

those of known titanosaurs. A simple fibular scaling with the present specimen of Camarasaurus supremus $(81.8 \mathrm{~cm}$ long) predicts a mass of $63273 \mathrm{~kg}$ for Argentinosaurus.

More reliable estimates should be obtained with the regression equations included in Table II. According to their correlation coefficients and $s_{v}$, the regressions computed on length of the femur (in a restricted sample without Amargasaurus and Mamenchisaurus), length of the tibia, length of the fibula, and cross-sectional area of the centrum of the second dorsal vertebra (in a restricted sample without Haplocanthosaurus) constitute the most reliable equations for body mass prediction of all the equations. It should be made clear that, in the cases of Antarctosaurus and Argentinosaurus, we had to extrapolate beyond the range of our observational data to estimate the body masses of these huge sauropods.

The femoral length of Argentinosaurus predicted with the regressions on femoral midshaft perimeter and also fibular length are 2525, 2486, and $2659 \mathrm{~mm}$, from equations 1,2 , and 3 , respectively (Table III). When its average is computed, the final length estimate is $2557 \mathrm{~mm}$. All of the above predicted lengths are highly similar, and are also nearly identical to Bonaparte's (1996b) length measurement for the complete femur referred to Argentinosaurus $(250 \mathrm{~cm})$. Thus, those values are within $2 \%$ of the length measured on that femur, which is considered a validation of the reliability of such predictions. On the other hand, those predictions indicate that the femoral fragment MLP-DP 46-VIII-21-3 and the complete femur belongs to individuals of the same size than the holotype. Consequently, the femoral midshaft perimeter measured in the former specimen and the femoral length measured in the latter were also used to estimate the body mass of Argentinosaurus.

Unfortunately, the length of the tibia and the distal width of the femur cannot be used to predict the body mass of Argentinosaurus (its tibiae were not found and the femur assigned to this species is distorted, as mentioned earlier). Hence, the body mass of Argentinosaurus has been computed from six regression equations, where the predicted values range from 60 to 88 tonnes (Table IV). When the average body mass is calculated, the result obtained is approximately 71 tonnes.

The multivariate regression equation of body mass on the length of the fibula and the crosssectional area of the centrum of the second

TABLE II Bivariate (geometric mean) regression equations of log-transformed (base-10) data for prediction of body mass in sauropods

\begin{tabular}{|c|c|c|c|c|c|c|}
\hline Equation & $X$ & $n$ & $\log u \pm 95 \%$ CI & $v \pm 95 \% \mathrm{CI}$ & $r$ & $F$ \\
\hline (1) & $\mathrm{fl}$ & 13 & $-5.983 \pm 2.780$ & $3.195 \pm 0.891$ & 0.907 & $51.268^{* *}$ \\
\hline (2) & $\mathrm{fl}^{*}$ & 11 & $-4.864 \pm 2.120$ & $2.838 \pm 0.677$ & 0.949 & $80.826^{* *}$ \\
\hline (3) & $\mathrm{fw}$ & 12 & $-3.589 \pm 2.882$ & $2.931 \pm 1.116$ & 0.842 & $24.274^{* *}$ \\
\hline (4) & $\mathrm{fw}^{+}$ & 11 & $-3.881 \pm 2.593$ & $3.030 \pm 1.000$ & 0.899 & $37.964^{* *}$ \\
\hline (5) & $\mathrm{fp}$ & 13 & $-4.166 \pm 2.291$ & $2.955 \pm 0.830$ & 0.906 & $50.388^{* *}$ \\
\hline (6) & $\mathrm{tl}$ & 12 & $-7.342 \pm 2.285$ & $3.876 \pm 0.782$ & 0.958 & $111.994^{* *}$ \\
\hline (7) & tp & 11 & $-4.507 \pm 3.829$ & $3.288 \pm 1.483$ & 0.801 & $16.157^{* * * *}$ \\
\hline (8) & fil & 11 & $-6.521 \pm 2.255$ & $3.594 \pm 0.771$ & 0.959 & $102.008^{* *}$ \\
\hline (9) & va & 10 & $-0.438 \pm 1.371$ & $0.980 \pm 0.304$ & 0.925 & $47.303^{* *}$ \\
\hline (10) & $\mathrm{va}^{+}$ & 9 & $-0.532 \pm 1.009$ & $0.994 \pm 0.222$ & 0.968 & $104.657^{* *}$ \\
\hline
\end{tabular}

$v$ and $u$ are the slope and antilog of the intercept in the regression equations, as $\log$ (body mass) $=v \log X+\log u$. In all cases, body masses are calculated in kilograms and bone dimensions are considered in millimetres. Abbreviations as in Table I. $(* *, P<0.001 ; * *$, $0.001<P<0.01)$. Excluding outliers Amargasaurus and Mamenchisaurus. +Excluding outlier Haplocanthosaurus. 
TABLE III Bivariate (geometric mean) regression equations of log-transformed (base-10) data for prediction of femoral length in Argentinosaurus

\begin{tabular}{lccrrrr}
\hline Equation & $X$ & $n$ & $\log u \pm 95 \% \mathrm{CI}$ & $v \pm 95 \% \mathrm{CI}$ & \multicolumn{1}{c}{$r$} \\
\hline$(1)$ & $\mathrm{fp}$ & 14 & $0.616 \pm 0.378$ & $0.907 \pm 0.136$ & 0.971 & $197.937^{* * *}$ \\
$(2)$ & $\mathrm{fp}^{*}$ & 13 & $0.640 \pm 0.305$ & $0.897 \pm 0.110$ & 0.983 & $310.375^{* * * *}$ \\
$(3)$ & $\mathrm{fil}$ & 11 & $-0.107 \pm 0.760$ & $1.107 \pm 0.260$ & 0.950 & $83.827^{* * *}$ \\
\hline
\end{tabular}

All bone dimensions are considered in millimeters. Abbreviations as in Table I. $\left({ }^{* *}, P<0.001\right)$. ${ }^{*}$ Excluding outlier Diplodocus.

dorsal vertebra is:

$$
\begin{aligned}
\log (\text { body mass })= & -3.226 \pm 2.460+1.562 \\
& \pm 1.298(\log \text { fibular length }) \\
& +0.581 \pm 0.362 \text { (log vertebral area) }
\end{aligned}
$$

where body mass is calculated in kilograms, and the bone measures, fibular length and vertebral area, are expressed in $\mathrm{mm}$ and $\mathrm{mm}^{2}$, respectively $(R=0.986$; $F=104.358 ; P<0.001)$. As expected the tolerance values, eigen values and condition index indicated substantial intercorrelation of the "independent" variables (condition index up to 142 and tolerance values of 0.201 ), but this is probably unavoidable in a biological sample where multiple measures are taken on the same animal. However, the partial regression coefficients are significant (two-tailed $t$-tests yield $P$ values of 0.029 and 0.009 , for the coefficients of fibular length and vertebral area, respectively), so redundancy of the selected predictor variables can be ruled out.

The multivariate equation mentioned above predicts a body mass of $72936 \mathrm{~kg}$ for Argentinosaurus. As the multivariate regression analysis not only has a higher correlation coefficient than any of the bivariate analyses, but also incorporates more anatomical dimensions (i.e. more information), we consider the latter value of 73 tonnes as the most likely and will use this figure in further discussion.

Antarctosaurus was also an enormous sauropod (Fig. 6). Two complete femora of the largest

TABLE IV Computed body masses of Argentinosaurus huinculensis and Antarctosaurus wichmannianus. Numbered equations are those defined in Table II

\begin{tabular}{lcc}
\hline Species & Equation used & Body mass $(\mathrm{kg})$ \\
\hline A. huinculensis & $(1)$ & 74,717 \\
& $(2)$ & 60,166 \\
& $(5)$ & 81,548 \\
& $(8)$ & 88,115 \\
A. wichmannianus & $(9)$ & 63,158 \\
& $(10)$ & 60,432 \\
& $(1)$ & 28,798 \\
& $(2)$ & 25,797 \\
$(3)$ & 35,790 \\
& $(4)$ & 34,419 \\
& $(5)$ & 33,473 \\
& $(6)$ & 47,611 \\
& $(7)$ & 30,182 \\
\hline
\end{tabular}

species, A. giganteus, are known. It seems, however, to have been smaller than Argentinosaurus, but clearly larger than Brachiosaurus. A simple geometric scaling of femoral and tibial lengths of the smaller species $A$. wichmannianus (measurements taken on specimens FMNH P13019 and FMNH P13020, respectively) to the specimen of $C$. supremus (Table I) yields body mass values of 24617 and $33410 \mathrm{~kg}$, respectively. This is roughly comparable to the values obtained with the regression equations from Table II. In those cases, the body masses range from about 26 to almost 48 tonnes (Table IV). Regression equations related to femoral length yielded body masses of nearly 29 tonnes (equation 1) and almost 26 tonnes (equation 2) for

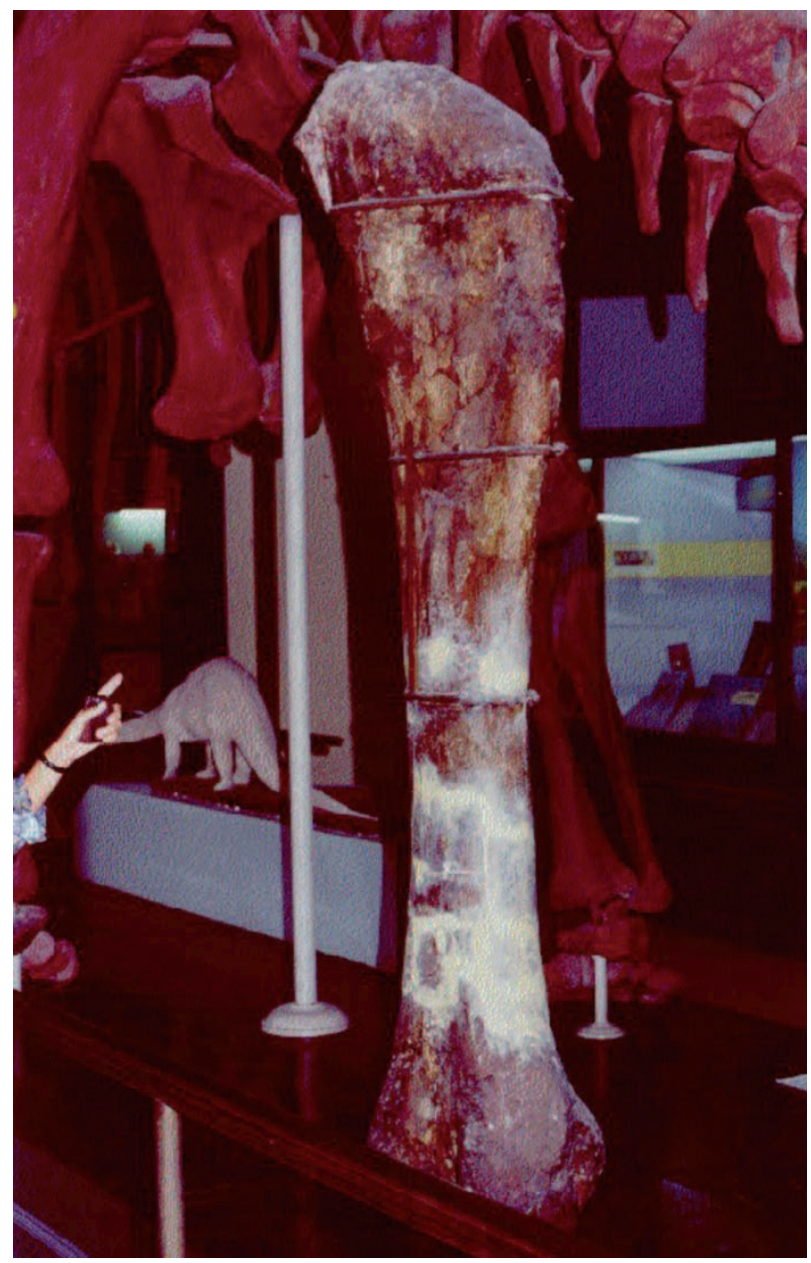

FIGURE 6 Femur of Antarctosaurus giganteus, exhibited in the Museo de La Plata besides a cast of Diplodocus carnegiei . 
A. wichmannianus, which are in the range of the values obtained with the geometric scaling mentioned above. The average of the seven body masses computed in Table IV is almost 34 tonnes.

A number of multivariate analyses were also performed on the bone dimensions of the sauropods from Table I, but these only resulted in marginally higher correlation coefficients compared to the bivariate regression equations in Table II.

The femur of A. wichmannianus (FMNH P13019) is, however, distinctly smaller $(1855 \mathrm{~mm})$ than the gigantic femur MLP 23-316 of A. giganteus $(2350 \mathrm{~mm})$. Assuming a geometric scaling with the FMNH specimen, which is reasonable since they could even be from the same species, results in a body mass of nearly 69 tonnes for $A$. giganteus, befitting for the name. Thus, this colossus was evidently not that much smaller than Argentinosaurus.

\section{Theropods}

A body mass of $1500 \mathrm{~kg}$ was estimated for C. sastrei using a volumetric procedure (Mazzetta et al., 1998). Here, its body mass was predicted from the appendicular bone measurements available in Bonaparte et al. (1990), using the regression equations obtained by Christiansen and Fariña (2004) (Table V). The average of the body mass values predicted is approximately $2100 \mathrm{~kg}$ and only one of them is about the value obtained through the volumetric estimation, while all the others are above that figure.

The disarticulated cranial bones of G. carolinii do not allow accurate size comparison with $T$. rex. A comparison between their respective appendicular bones shows that the femur of Giganotosaurus $(1.43 \mathrm{~m}$ long) is about $5 \mathrm{~cm}$ longer than that of "Sue" (FMNH PR2081), although the tibia ( $1.12 \mathrm{~m}$ long) is $8 \mathrm{~cm}$ shorter, as is common in more plesiomorphic carnosaurs sensu Gauthier (1986) (see Christiansen and Bonde, 2002). Most bones included in the holotype of Giganotosaurus (MUCPv-CH-1) indicate that this species was at least similar in size to the largest known Tyrannosaurus specimens, or even bigger if one considers the fragmentary dentary specimen MUCPv-95 (Calvo and Coria, 1998). Hence, assuming equal size between the holotype specimen of Giganotosaurus and the robust morph of Tyrannosaurus, a body mass of about 8 tonnes could be considered for the former taking into account reliable body mass estimates for the biggest specimens of Tyrannosaurus (Paul, 1997; Henderson, 1999). On the other hand, assuming geometric similarity with the holotype specimen of Giganotosaurus, a body mass of about 10 tonnes is estimated for the individual corresponding to the specimen MUCPv-95 (the ratio of dentary lengths between them is 0.926 , therefore its body mass is $8 \times 1.08^{3}=$ 10.1 tonnes).

However, tyrannosaurids are very apomorphic, and therefore a better comparison should be made with the more plesiomorphic (and much closer related) carnosaurs Allosaurus and Sinraptor (data published in Christiansen, 1998). A simple length comparison between Giganotosaurus and Allosaurus predicts a body mass of $7796 \mathrm{~kg}$ using the femur and $5460 \mathrm{~kg}$ using the tibia. The latter may not be too reliable since big carnosaurs become more stubby-legged. When compared with the $1700-\mathrm{kg}$ Sinraptor dongi, the body mass predictions for Giganotosaurus are 7196 and $4364 \mathrm{~kg}$, using the lengths of femur and tibia, respectively.

More reliable body mass estimates for Giganotosaurus are shown in Table VI. Those estimates were obtained using the equations derived from the database of theropods cited above (Christiansen and Fariña, 2004). The average of bivariate equations is $5604 \mathrm{~kg}$, but it includes a very low value predicted from the distal lateromedial diameter of the femur $(2369 \mathrm{~kg})$. If this outlier is excluded, the average amounts to $6143 \mathrm{~kg}$. Multivariate equations, on the other hand, yielded an average of $6510 \mathrm{~kg}$. Four equations yielded very low body mass estimates (between 3828 and $4418 \mathrm{~kg}$ ), while two others produced very high estimates (9268 and 10,709 kg). If the four lower values in Table VI are excluded, the average is $6846 \mathrm{~kg}$, while if the two higher values are not taken into account, the average is $6278 \mathrm{~kg}$. Finally, the average without the six outliers is $6604 \mathrm{~kg}$.

TABLE V Body mass estimates for Carnotaurus sastrei. Predictions based on bivariate and multivariate regression equations (Christiansen and Fariña, 2004). (Bone measurements are from Bonaparte et al., 1990)

\begin{tabular}{lcc}
\hline Bone dimension $(\mathrm{kg})$ & Measurement (mm) & Body mass \\
\hline Femoral length & 1030 & 2626 \\
Femoral midshaft anteroposterior diameter & $\sim 100$ & 100 \\
Femoral midshaft lateromedial diameter & 197.5 & - \\
Femoral distal lateromedial diameter & 70 & 1485 \\
Tibial midshaft anteroposterior diameter & - & - \\
Femoral length and Femoral midshaft lateromedial diameter & - & 2415 \\
Femoral length and Femoral distal lateromedial diameter & - & 2361 \\
Femoral length and Tibial midshaft anteroposterior diameter & - & - \\
Femoral midshaft anteroposterior diameter and Femoral distal lateromedial diameter & - & 2109 \\
Average & & 2339 \\
\hline
\end{tabular}


TABLE VI Body mass estimates for Giganotosaurus carolinii. Predictions based on bivariate and multivariate regression equations (Christiansen and Fariña, 2004)

\begin{tabular}{|c|c|}
\hline Bone dimension & Body mass $(\mathrm{kg}$ \\
\hline \multicolumn{2}{|l|}{ Bivariate analyses: } \\
\hline Femoral length & 7532 \\
\hline Femoral midshaft perimeter & 6167 \\
\hline Femoral midshaft anteroposterior diameter & 6220 \\
\hline Femoral distal lateromedial diameter & $2369^{*}$ \\
\hline Tibial midshaft perimeter & 6704 \\
\hline Tibial distal lateromedial diameter & 4884 \\
\hline Fibular proximal anteroposterior diameter & 5353 \\
\hline Average & 5604 \\
\hline \multicolumn{2}{|l|}{ Multivariate analyses: } \\
\hline Femoral length and least perimeter & 7017 \\
\hline $\begin{array}{l}\text { Femoral length and Femoral } \\
\text { midshaft lateromedial diameter }\end{array}$ & 7204 \\
\hline $\begin{array}{l}\text { Femoral length and Femoral } \\
\text { distal lateromedial diameter }\end{array}$ & 6053 \\
\hline $\begin{array}{l}\text { Femoral length and Tibial midshaft } \\
\text { perimeter }\end{array}$ & 7296 \\
\hline $\begin{array}{l}\text { Femoral length and Tibial midshaft } \\
\text { anteroposterior diameter }\end{array}$ & 6885 \\
\hline $\begin{array}{l}\text { Femoral length and Tibial midshaft } \\
\text { lateromedial diameter }\end{array}$ & 7676 \\
\hline $\begin{array}{l}\text { Femoral length and Tibial distal } \\
\text { lateromedial diameter }\end{array}$ & 6758 \\
\hline $\begin{array}{l}\text { Femoral length and Fibular distal } \\
\text { anteroposterior diameter }\end{array}$ & 7901 \\
\hline $\begin{array}{l}\text { Femoral length and Fibular distal } \\
\text { lateromedial diameter }\end{array}$ & 7955 \\
\hline $\begin{array}{l}\text { Femoral midshaft perimeter and } \\
\text { Tibial length }\end{array}$ & 5332 \\
\hline $\begin{array}{l}\text { Femoral perimeter and Tibial midshaft } \\
\text { lateromedial diameter }\end{array}$ & 6581 \\
\hline $\begin{array}{l}\text { Femoral midshaft perimeter and } \\
\text { Tibial distal lateromedial diameter }\end{array}$ & 5808 \\
\hline $\begin{array}{l}\text { Femoral midshaft anteroposterior diameter } \\
\text { and Femoral distal lateromedial diameter }\end{array}$ & $4255^{*}$ \\
\hline $\begin{array}{l}\text { Femoral midshaft anteroposterior diameter } \\
\text { and Tibial midshaft perimeter }\end{array}$ & 6439 \\
\hline $\begin{array}{l}\text { Femoral midshaft anteroposterior diameter } \\
\text { and Tibial midshaft anteroposterior } \\
\text { diameter }\end{array}$ & 5525 \\
\hline $\begin{array}{l}\text { Femoral midshaft anteroposterior diameter } \\
\text { and Tibial distal lateromedial diameter }\end{array}$ & 5598 \\
\hline $\begin{array}{l}\text { Femoral midshaft anteroposterior diameter } \\
\text { and Fibular midshaft perimeter }\end{array}$ & 8470 \\
\hline $\begin{array}{l}\text { Femoral midshaft anteroposterior diameter } \\
\text { and Fibular midshaft lateromedial } \\
\text { diameter }\end{array}$ & 7370 \\
\hline $\begin{array}{l}\text { Femoral midshaft anteroposterior diameter } \\
\text { and Fibular distal anteroposterior } \\
\text { diameter }\end{array}$ & 6451 \\
\hline $\begin{array}{l}\text { Femoral distal lateromedial diameter } \\
\text { and Tibial midshaft perimeter }\end{array}$ & 4868 \\
\hline $\begin{array}{l}\text { Femoral distal lateromedial diameter } \\
\text { and Tibial midshaft lateromedial } \\
\text { diameter }\end{array}$ & $4137^{*}$ \\
\hline $\begin{array}{l}\text { Tibial length and Fibular midshaft } \\
\text { perimeter }\end{array}$ & 7184 \\
\hline $\begin{array}{l}\text { Tibial length and Fibular distal } \\
\text { anteroposterior diameter }\end{array}$ & $4418^{*}$ \\
\hline $\begin{array}{l}\text { Tibial midshaft perimeter and Fibular } \\
\text { midshaft perimeter }\end{array}$ & 7524 \\
\hline $\begin{array}{l}\text { Tibial midshaft perimeter and Fibular } \\
\text { midshaft lateromedial diameter }\end{array}$ & 6898 \\
\hline $\begin{array}{l}\text { Tibial midshaft perimeter and Fibular distal } \\
\text { anteroposterior diameter }\end{array}$ & 6404 \\
\hline $\begin{array}{l}\text { Tibial midshaft perimeter and Fibular distal } \\
\text { lateromedial diameter }\end{array}$ & 6259 \\
\hline $\begin{array}{l}\text { Tibial midshaft lateromedial diameter } \\
\text { and Fibular midshaft perimeter }\end{array}$ & $10709^{+}$ \\
\hline
\end{tabular}

TABLE VI - continued

\begin{tabular}{lc} 
Bone dimension & Body mass $(\mathrm{kg})$ \\
\hline $\begin{array}{l}\text { Tibial midshaft lateromedial diameter } \\
\text { and Fibular midshaft lateromedial } \\
\text { diameter }\end{array}$ & $9268^{+}$ \\
$\begin{array}{l}\text { Tibial midshaft lateromedial diameter } \\
\text { and Fibular distal lateromedial } \\
\text { diameter }\end{array}$ & 4758 \\
$\begin{array}{l}\text { Tibial distal lateromedial diameter } \\
\text { and Fibular length }\end{array}$ & $3828^{*}$ \\
$\begin{array}{l}\text { Fibular proximal anteroposterior diameter } \\
\text { and Fibular distal anteroposterior } \\
\text { diameter }\end{array}$ & 5500 \\
Average & 6510 \\
\hline
\end{tabular}

* Too low values. ${ }^{\dagger}$ Too high values.

\section{DISCUSSION}

\section{Sauropods}

Gregory (1905) was probably the first to report on body mass prediction in a sauropod. Based on the reconstruction designed by Charles Knight, a model of the skeletal mount of Apatosaurus excelsus was made, and the estimation of its body mass yielded 31 tonnes, clearly due to erroneous body proportions and a very portly design. Errors in model proportions are particularly liable to lead to inflated body mass estimates (Paul, 1997; Christiansen, 2000).

Among those sauropods studied here, Amargasaurus is clearly the smaller. As mentioned above, the estimated body mass of this bizarre-looking, small sauropod was about two and a half tonnes. The other sauropods in this paper are real giants, and must be compared with the largest known dinosaurs ever found. Brachiosaurus has traditionally been considered one of the largest, if not the largest, sauropod known, and for many years this was probably true. However, this is clearly not the case anymore. Colbert (1962) was the first researcher to report on the body mass of Brachiosaurus, but he also used a badly proportioned model. Additionally, he used a wrong scale. Brachiosaurus does not, as reported by Colbert (1962), stand $609 \mathrm{~cm}$ at the hips, but rather an estimated height of $540 \mathrm{~cm}$ (Paul, 1988), and the scaling error alone would lead to a body mass of $63,400 \mathrm{~kg}$, not the widely cited value of $78,300 \mathrm{~kg}$. More accurate reconstructions predict a body mass for Brachiosaurus of 32 (Paul, 1988; Paul, 1997) to 37 tonnes (Christiansen, 1997). However, note that in the latter paper the body mass is closer to 40 tonnes due to the higher density used in the calculations. Alexander (1989) computed a body mass of 47 tonnes for Brachiosaurus, based on the commercial model from the British Museum (Natural History), which is also proportionally inaccurate (Paul, 1997; Christiansen, 2000). Ironically, the new, lower body mass estimates for Brachiosaurus are very similar to the first estimate of 40 tonnes, based 
simply on Werner Janensch's personal opinion (Janensch, 1938).

Impressive as this undeniably is, Brachiosaurus is, however, clearly not the largest dinosaur known. This title currently befalls to Argentinosaurus. It probably did not, however, reach the figure of 100 tonnes, proposed as the more conservative upper mass limit for a land tetrapod by Hokkanen (1986), unless some specimens were much larger than the holotype. Unfortunately, this cannot be checked until new findings are produced. Other dinosaurs are known, however, that may have approached Argentinosaurus in body mass. "Ultrasauros" (Jensen, 1985) was said to be of extraordinarily colossal dimensions, often credited with a body mass of 100 tonnes or more (e.g. Ostrom, 1978; Benton, 1988; Gillette, 1994). In reality, the scapulocoracoid $(250 \mathrm{~cm}$ long, not $270 \mathrm{~cm}$ as stated in Jensen, 1985) of "Ultrasauros" cannot be shown to be different from those of the genus Brachiosaurus (Curtice and Curtice, 1996), and it could well belong to the type species B. altithorax. It is from a specimen larger than the holotype FMNH 25107, but not by more than around 10 or so tonnes (Paul, 1988; Curtice and Curtice, 1996). It probably had a mass of 45-50 tonnes. Additionally, equally large remains of $B$. brancai have been known, but clearly not discussed, for nearly a century. The scapula on HMN SII is nearly as large $(193 \mathrm{~cm}$, scapulocoracoid $238 \mathrm{~cm})$, and an even larger scapula $(203.5 \mathrm{~cm})$ is on exhibition at the Museum für Naturkunde, Berlin (Christiansen, Personal observation). This is as large as that of "Ultrasauros". The reported dorsal vertebra of "Ultrasauros" is not even brachiosaurian but from a diplodocid (Curtice and Curtice, 1996). The type specimen of "Ultrasauros" was not the scapulocoracoid but that large diplodocid dorsal vertebra, now referred to Supersaurus (Britt and Curtice, 1997).

Supersaurus (Jensen, 1985) is a huge diplodocid, and at an estimated body mass of around 50 tonnes it is the largest diplodocid for which there are substantial remains (Paul, 1988, 1997). Seismosaurus halli (Gillette, 1987, 1991) is not as large, and claims of a body length of $50 \mathrm{~m}$ (Gillette, 1994) are based on dimensions other than vertebral lengths. Paul (1997) estimated that this animal would have had a body mass of around 30 tonnes, at an overall length of $32-35 \mathrm{~m}$. The only other sauropods which could have been subequal in size to Argentinosaurus are known from only very fragmentary remains. Sauroposeidon proteles is a gigantic brachiosaurid (Wedel et al., 2000a) that appears to have been substantially larger than B. brancai HMN SII. However, it would probably not have had a greater body mass than Argentinosaurus, and Wedel et al. (2000b) suggested that it probably had a mass of 50-60 tonnes, subequal to $A$. giganteus.

The incomplete vertebra of the diplodocid Amphicoelias fragillimus (Cope, 1878) apparently was of colossal dimensions, indicating an animal potentially larger than even Argentinosaurus (Appenzeller, 1994; Paul, 1994, 1997). However, this vertebra has been lost for more than a century, making its true size and phylogenetic affinities uncertain.

Recently, Smith et al. (2001) described the partial skeleton of Paralititan stromeri, an extremely large titanosaurian sauropod from the Late Cretaceous of the Bahariya Oasis, Egypt. However, and according to these authors, this new species is probably not as large as Argentinosaurus but represents one of the biggest terrestrial vertebrates yet discovered.

Finally, one of the included species in this analysis (A. giganteus) is also one of the largest dinosaurs ever discovered. The huge bones of the holotype have long been regarded as remains of one of the largest of all sauropods known. Paul (1988) estimated its body mass at 40-50 tonnes, but our results indicate that this value is too low. Janensch (1938) noted that its femora were the largest long bones from any known sauropod, and with the exception of the only known complete femur of Argentinosaurus, this still holds true today. However, its femoral length is $235 \mathrm{~cm}$, not $231 \mathrm{~cm}$ as given by most previous authors. Van Valen (1969) estimated that $A$. giganteus had a body mass of around 80 tonnes, based mainly on comparisons with Colbert's (1962) inflated mass of 78 tonnes for Brachiosaurus. As explained earlier, our body mass estimation for $A$. giganteus yielded a figure of about 69 tonnes, which is intermediate to those pointed out for previous authors.

\section{Theropods}

As mentioned above, a volumetric procedure yielded a body mass estimate of $1500 \mathrm{~kg}$ for C. sastrei (Mazzetta et al., 1998). The body mass overestimates obtained here by the usage of allometric equations based on limb bone dimensions may be due to the phylogenetic composition of the database in Christiansen and Fariña (2004), mostly integrated by very advanced forms, such as the very closely related tyrannosaurs and ornithomimids. As a primitive theropod (clade Abelisauridae), Carnotaurus is substantially different in several respects from the more advanced ones (Bonaparte et al., 1990; Novas, 1997a,b). In any event, this discrepancy does not affect the conclusion on its locomotor capabilty proposed by Mazzetta et al. (1998). Such a conclusion states that the femoral strength indicator (quantity inversely related to the body mass) of Carnotaurus was high enough to endure strenous activities, suggesting that it may have preyed upon fast-moving, rather small prey.

On the other hand, G. carolinii must have been one of the largest theropods ever found, and even the largest. With a body mass of about six tonnes and a half (when only the predictions based on 
the multivariate regression equations are taken into account), its size must have been lower than those corresponding to "Sue", the largest specimen of T. rex. Nevertheless, the individual corresponding to the dentary MUCPV-95 exceeds the size of "Sue", even considering an estimation of its body mass based on a simple geometric scaling with a 6.5-tonnes holotype specimen. In this case, its body mass is $6.5 \times 1.08^{3}=8.2$ tonnes (since its dentary is $8 \%$ longer than that of the holotype, as mentioned above). Hence, with a body mass above 8 tonnes, this individual must have been the largest theropod ever found, as well as the largest terrestrial carnivore of all times.

\section{Acknowledgements}

The authors thanks R.E. Blanco for his assistance during body mass calculation. R.McN. Alexander and P.M. Barrett gave us useful advice and made comments on earlier versions of the manuscript. We are indebted to S.F. Vizcaíno and other staff from La Plata Museum, and J.F. Bonaparte from the Museo Argentino de Ciencias Naturales for their help in measuring the specimens. L. Quagliotto kindly provided us with the photographs of Fig. 3. L. Salgado and R.A. Coria warned one of us (G.V.M.) about the possibility that the "tibia" of the holotype of Argentinosaurus was actually a fibula.

\section{References}

Alexander, R.McN. 1985. Mechanics of posture and gait of some large dinosaurs. Zoological Journal of the Linnean Society 83, 1-25.

Alexander, R.McN. 1989. Dynamics of Dinosaurs and Other Extinct Giants. Columbia University Press, New York.

Appenzeller, T. 1994. Argentine dinos vie for heavyweight titles. Science 266, 1805.

Ardolino, A. and Delpino, D. 1987. Senoniano (continentalmarino), Comarca Nordpatagónica, Provincia del Chubut, Argentina. Actas X Congreso Geológico Argentino 3, 193-196.

Benton, M.J. 1988. Dinosaurs: An A-Z Guide. Grisewood and Dempsey Ltd., London.

Benton, M.J. 1990. Evolution of large size. In Briggs, D.E.G. and Crowther, P.R. (eds), Palaeobiology: A Synthesis, pp 147-152. Blackwell Scientific, Oxford.

Blanco, R.E. and Mazzetta, G.V. 2001. A new approach to evaluate the cursorial ability of the giant theropod Giganotosaurus carolinii. Acta Palaeontologica Polonica 46, 193-202.

Bonaparte, J.F. 1985. A horned Cretaceous carnosaur from Patagonia. National Geographic Research 1, 149-151.

Bonaparte, J.F. 1986. History of the terrestrial Cretaceous vertebrates of Gondwana. Actas IV Congreso Argentino de Paleontología y Bioestratigrafía 2, 63-95.

Bonaparte, J.F. 1996a. Cretaceous tetrapods of Argentina. Münchner Geowissenschaftliche Abhandlungen (A) 30, 73-130.

Bonaparte, J.F. 1996b. Dinosaurios de América del Sur. Museo Argentino de Ciencias Naturales, Buenos Aires.

Bonaparte, J.F. and Kielan-Jaworowska, Z. 1987. Late Cretaceous dinosaur and mammal faunas of Laurasia and Gondwana. In Currie, P.J. and Koster, E.H. (eds), Fourth Symposium in Mesozoic Terrestrial Ecosystems, Short papers, pp. 24-29.

Bonaparte, J.F., Novas, F.E. and Coria, R.A. 1990. Carnotaurus sastrei Bonaparte, the horned, lightly built carnosaur from the Middle Cretaceous of Patagonia. Contributions in Science, Los Angeles County Museum 416, 1-42.
Bonaparte, J.F. and Coria, R.A. 1993. Un nuevo y gigantesco saurópodo titanosaurio de la Formación Río Limay (AlbianoCenomaniano) de la Provincia del Neuquén, Argentina. Ameghiniana 30, 271-282.

Borsuk-Bialynicka, M. 1977. A new camarasaurid sauropod Opisthocoelicaudia skarzynskii gen n., sp. n. from the Upper Cretaceous of Mongolia. Palaeontologia Polonica 37, $1-64$.

Britt, B.B. and Curtice, B.D. 1997. Dry Mesa quarry. In Currie, P.J. and Padian, K. (eds), Encyclopedia of Dinosaurs. Academic Press, San Diego, p 196.

Calvo, J.O. and Coria, R.A. 1998. New specimen of Giganotosaurus carolinii (Coria and Salgado, 1995), supports it as the largest theropod ever found. In Pérez-Moreno, B.P., Holtz, T.R., Jr., Sanz, J.L. and Moratalla, J.J. (eds), Aspects of Theropod Palaeobiology, Gaia Special Volume, pp. 117-122. Lisbon.

Casamiquela, R.M. 1978. La zona litoral de la transgresión maastrichtiense en el norte de la Patagonia, Aspectos ecológicos. Ameghiniana 15, 137-148.

Christian, A., Heinrich, W.-D. and Golder, W. 1999. Posture and mechanics of the forelimbs of Brachiosaurus brancai (Dinosauria: Sauropoda). Mitteilungen aus dem Museum für Naturkunde in Berlin. Geowissenschaftlicher Reihe 2, 63-73.

Christiansen, P. 1996. The 'whiplash' tail of diplodocid sauropods: Was it really a weapon? In Morales, M. (ed), The Continental Jurassic, pp 51-58. Museum of Northern Arizona, Flagstaff.

Christiansen, P. 1997. Locomotion in sauropod dinosaurs. Gaia 14, 45-75.

Christiansen, P. 1998. Strength indicator values of theropod long bones, with comments on limb proportions and cursorial potential. In Pérez-Moreno, B.P., Holtz, T.R., Jr., Sanz, J.L. and Moratalla, J.J. (eds), Aspects of Theropod Palaeobiology, Gaia Special Volume, pp. 241-255, Lisbon.

Christiansen, P. 2000. Dinosaur biomechanics. In Paul, G.S. (ed) The Scientific American Book of Dinosaurs, pp 64-77. Byron Press Inc., New York.

Christiansen, P. 2002. Mass allometry of the appendicular skeleton in terrestrial mammals. Journal of Morphology 251, 195-209.

Christiansen, P. and Bonde, N. 2002. Limb proportions and avian terrestrial locomotion. Journal of Ornithology 143, 356-371.

Christiansen, P. and Fariña, R.A. 2004. Mass prediction in theropod dinosaurs. Historical Biology.

Colbert, E.H. 1962. The weights of dinosaurs. American Museum Novitates 2076, 1-16.

Cope, E.D. 1878. A new species of Amphicoelias. American Naturalist $12,563-565$.

Coria, R.A. and Salgado, L. 1995. A new giant carnivorous dinosaur from the Cretaceous of Patagonia. Nature 377, 224-226.

Curtice, B.D. and Curtice, L.J. 1996. Death of a dinosaur-a reevaluation of Ultrasauros macintoshi. Journal of Vertebrate Paleontology 16(Suppl. 3), 29A.

Gauthier, J.A. 1986. Saurischian monophyly and the origin of birds. Memoirs of the California Academy of Science 8, 1-55.

Gillette, D.D. 1987. A giant sauropod from the Jackpile SS Member of the Morrison Formation (Upper Jurassic) of New Mexico. Journal of Vertebrate Paleontology 7(Suppl. 3), 16A-17A.

Gillette, D.D. 1991. Seismosaurus halli, gen. et sp. nov. A new sauropod dinosaur from the Morrison Formation (Upper Jurassic/Lower Cretaceous) of New Mexico. Journal of Vertebrate Paleontology 11, 417-433.

Gillette, D.D. 1994. Seismosaurus-The Earth Shaker. Columbia University Press, New York.

Gregory, W.K. 1905. The weight of the Brontosaurus. Science (NS) 22, 572.

Gunga, H.C., Kirsch, K.A., Baartz, F., Röcker, L., Heinrich, W.-D., Lisowski, W., Weidemann, A. and Albertz, J. 1995. New data on the dimensions of Brachiosaurus brancai and their physiological implications. Naturwissenschaften 82, 190-192.

Henderson, D.M. 1986. Estimating the masses and centers of mass of extinct animals by 3-D mathematical slicing. Paleobiology 25, 88-106. 
Hokkanen, J.E.I. 1999. The size of the largest land animal. Journal of Theoretical Biology 118, 491-499.

Horner, J.R. and Lessem, D. 1993. The complete T. rex. Simon and Schuster, New York.

Hutchinson, J.R. and Padian, K. 1997. Carnosauria. In Currie, P.J. and Padian, K. (eds), Encyclopedia of Dinosaurs, pp 94-97. Academic Press, San Diego.

Janensch, W. 1938. Gestalt und grösse von Brachiosaurus und anderen reisenwüchsigen Sauropoden. Der Biologe 7, 130-134.

Janensch, W. 1950. Die Skelettrekonstruktion von Brachiosaurus brancai. Palaeontographica 3(Suppl. 7), 95-103.

Jensen, J.A. 1985. Three new sauropod dinosaurs from the Upper Jurassic of Colorado. Great Basin Naturalist 45, 697-709.

Mazzetta, G.V. and Blanco, R.E. 2001. Speeds of dinosaurs from the Albian-Cenomanian of Patagonia and sauropod stance and gait. Acta Palaeontologica Polonica 46, 235-246.

Mazzetta, G.V., Fariña, R.A. and Vizcaíno, S.F. 1998. On the palaeobiology of the South American horned theropod Carnotaurus sastrei Bonaparte. In Pérez-Moreno, B.P., Holtz, T.R., Jr., Sanz, J.L. and Moratalla, J.J. (eds), Aspects of Theropod Paleobiology, Gaia Special Volume, pp. 185-192. Lisbon.

Norman, D. 1985. The Illustrated Encyclopedia of Dinosaurs. Salamander Books, London.

Novas, F.E. 1997a. Abelisauridae. In Currie, P.J. and Padian, K. (eds), Encyclopedia of Dinosaurs, pp 1-2. Academic Press, San Diego.

Novas, F.E. 1997b. South American dinosaurs. In Currie, P.J. and Padian, K. (eds), Encyclopedia of Dinosaurs, pp 678-689. Academic Press, San Diego.

Ostrom, J.H. 1978. A new look at dinosaurs. National Geographic $154,152-185$.

Paul, G.S. 1988. The brachiosaur giants of the Morrison and Tendaguru with a description of a new subgenus, Giraffatitan, and a comparison of the world's largest dinosaurs. Hunteria 2, $1-14$.

Paul, G.S. 1994. Is Garden Park home to the world's largest known land animal? Garden Park Paleontology Society 4, 5.

Paul, G.S. 1997. Dinosaur models: the good, the bad, and using them to estimate the mass of dinosaurs. In Wolberg, D.L., Stump, E. and Rosenberg, G.D. (eds), DinoFest International Proceedings, pp 129-154. The Academy of Natural Sciences, Philadelphia.

Ricker, W.E. 1984. Computation and uses of central trend lines. Canadian Journal of Zoology 62, 1897-1905.

Salgado, L. and Bonaparte, J.F. 1991. Un nuevo saurópodo Dicraeosauridae, Amargasaurus cazaui gen. et sp. nov., de la
Formación La Amarga, Neocomiano de la Provincia del Neuquén, Argentina. Ameghiniana 28, 333-346.

Salgado, L., Coria, R.A. and Calvo, C.O. 1997a. Evolution of titanosaurid sauropods. I: Phylogenetic analyses based on postcranial evidence. Ameghiniana 34, 3-32.

Salgado, L., Coria, R.A. and Calvo, C.O. 1997b. Evolution of titanosaurid sauropods. II: The cranial evidence. Ameghiniana 34, 33-48.

Sampson, S.D., Witmer, L.M., Forster, C.A., Krause, D.W., O'Connor, P.M., Dodson, P. and Ravoavy, F. 1998. Predatory dinosaur remains from Madagascar: implications for the Cretaceous biogeography of Gondwana. Science 280, 1048-1051.

Sereno, P.C., Dutheil, D.B., Iarochene, M., Larsson, H.C.E., Lyon, G.H., Magwene, P.M., Sidor, C.A., Varricchio, D.J. and Wilson, J.A. 1996. Predatory dinosaurs from the Sahara and Late Cretaceous faunal differentiation. Science 272, 986-991.

Smith, J.B., Lamanna, M.C., Lacovara, K.J., Dodson, P., Smith, J.R., Poole, J.C., Giegengack, R. and Attia, Y. 2001. A giant sauropod dinosaur from an Upper Cretaceous mangrove deposit in Egypt. Science 292, 1704-1706.

Sokal, R.R. and Rohlf, F.J. 1995. Biometry: The Principles and Practice of Statistics in Biological Research., 3rd ed. W.H. Freeman and Co., New York.

Upchurch, P. 1995. The evolutionary history of sauropod dinosaurs. Philosophical Transactions of the Royal Society (Ser. B) 349, 365-390.

Van Valen, L. 1969. What was the largest dinosaur? Copeia 1969, 624-625.

Von Huene, F. 1929. Los saurisquios y ornitisquios del Cretáceo Argentino. Anales del Museo de La Plata 3, 1-196.

Wedel, M.J., Cifelli, R.L. and Sanders, R.K. 2000a. Sauroposeidon proteles, a new sauropod from the early Cretaceous of Oklahoma. Journal of Vertebrate Paleontology 20, 109-114.

Wedel, M.J., Cifelli, R.L. and Sanders, R.K. 2000b. Osteology, paleobiology, and relationships of the sauropod dinosaur Sauroposeidon. Acta Palaeontologica Polonica 45, 343-388.

Wilson, J.O. and Sereno, P.C. 1998. Early evolution and higherlevel phylogeny of sauropod dinosaurs. Journal of Vertebrate Paleontology 18(Suppl. 2), 1-68, Memoir 5.

Wing, S.L. and Sues, H.D. and eight others 1992. Mesozoic and early Cenozoic terrestrial ecosystems. In Behrensmeyer, A.K., Damuth, J.D., DiMichele, W.A., Potts, R., Sues, H.D. and Wing, S.L. (eds), Terrestrial Ecosystems through Time, pp 327-416. University of Chicago Press, Chicago. 